\title{
Contact zone between chromosomal races of Mus musculus domesticus. 2. Fertility and segregation in laboratory-reared and wild mice heterozygous for multiple Robertsonian rearrangements
}

\author{
RICCARDO CASTIGLIA* \& ERNESTO CAPANNA \\ Dipartimento di Biologia Animale e dell' Uomo, Università di Roma 'La Sapienza'-Via A. Borelli 50, \\ 00161 Rome, Italy
}

\begin{abstract}
Litter size, anaphase I nondisjunction and $\mathrm{X}-\mathrm{Y}$ dissociation at metaphase I were studied in homozygous and heterozygous house mice from a central Italian chromosomal hybrid zone between the CD $(2 n=22)$ race and the standard race $(2 n=40)$. We also observed the segregation of the two chromosomal forms (Robertsonian and non-Robertsonian) in male and female multiple heterozygotes from the karyotype of their offspring and chromosomal arm counts of metaphase II. Litter size was significantly reduced in the F1 hybrids, but there was no difference in litter size between male and female F1s. Fertility in wild mice decreased with increasing numbers of structural heterozygosities (0-5). Some metacentrics appear to be under meiotic drive but there was no rule as to which of the two forms was favoured in backcrosses. An original observation of a negative correlation between the length of metacentrics and transmission rate was described in hybrids. Slight cosegregation of chromosomes with a similar morphology was present in the progeny of males and females. These observations are discussed in relation to the stability of this hybrid zone through time.
\end{abstract}

Keywords: chromosomal evolution, house mouse, litter size, malsegregation, meiotic segregation, $\mathrm{Rb}$ fusion.

\section{Introduction}

Chromosomal polytypism in the house mouse Mus musculus domesticus has been studied widely since the paper of Gropp et al. (1969). Many chromosomal races with a low diploid number have been found in Europe and North Africa (for a review see Sage et al., 1992). The formation of such races is due to the fixation and accumulation of Robertsonian ( $\mathrm{Rb}$ ) translocations formed by the centric fusion of telocentric chromosomes (Capanna, 1982) and possibly by whole arm reciprocal translocation (WART) between metacentric chromosomes (Castiglia \& Capanna, 1999a and references therein). Hybrid zones are formed where a $\mathrm{Rb}$ race comes into contact with the standard 40 all telocentric race or when two $\mathrm{Rb}$ races meet. In order to understand the process of race formation, it is important to ascertain if chromosomal differences can influence the fitness of hybrid individuals and if the $\mathrm{Rb}$ metacentric is

*Correspondence. E-mail: Castiglia@uniroma1.it (C) 2000 The Genetical Society of Great Britain. itself under some kind of selection. Hybrid individuals show nonbivalent configurations at metaphase I (MI): trivalent (chain of three) configurations if they are heterozygous for one or more fusions with no homology ('single' or 'multiple simple heterozygotes'); longer chains and rings are seen if the heterozygous fusions have monobrachial homology ("complex heterozygotes').

Studies of heterozygotes derived from wild populations have shown that the presence of one or three trivalents at meiosis may have little effect on fertility (Winking et al., 1988; Britton-Davidian et al., 1990; Scriven, 1992; Viroux \& Bauchau, 1992; Wallace et al., 1992), whereas many trivalents or longer chains or rings may reduce fertility to the point of sterility (Said et al., 1993; Hauffe \& Searle, 1998). Moreover, heterozygotes are expected to have a lower lifetime reproductive success as a consequence of germ cell death in both males (Redi et al., 1985) and females (Garagna et al., 1989). Among these authors, only Hauffe \& Searle (1998) have carried out a complete analysis of 
the fertility of individuals with single and multiple heterozygosities belonging to the same hybrid zone. These authors found that the values of germ cell death (GCD) and of anaphase I nondisjunction (NDJ) do not always agree with the direct estimates given by the litter size.

Among the factors favouring chromosomal fixation, meiotic drive can be a very strong force causing a $\mathrm{Rb}$ metacentric to spread in a given population (Nachman \& Searle, 1995). Britton-Davidian et al. (1990), Nance et al. (1990) and Viroux \& Bauchau (1992) found no deviation from Mendelian segregation in mice with single heterozygosities for $\mathrm{Rb}(16.17), \mathrm{Rb}(3.8)$ and $\mathrm{Rb}(4.12)$, respectively, whereas meiotic drive in favour of $\mathrm{Rb}(9.12)$ was observed by Harris et al. (1986). In hybrids between $M . m$. domesticus and M.m. musculus, Lenormand et al. (1997) uncovered selective processes involving embryo competition, with non- $\mathrm{Rb}$ carriers being favoured during preimplantation, but disadvantaged during the postimplantation stage.

Spirito et al. (1980) analysed a $14 \mathrm{~km}$-wide transect through a hybrid zone in central Italy, between the standard race $2 n=40$ and the CD race $(2 n=22)$. They found that the NDJ values increased with increasing number of trivalents in males (Rizzoni \& Spirito, 1998), and, in two multiple heterozygotes, they observed a nonrandom segregation of chromosomes of the same form: in metaphase II (MII), metacentrics cosegregated with metacentrics, and telocentrics with telocentrics (Rizzoni \& Spirito, 1999).

A temporal analysis, conducted 20 years after the original study of the same transect, showed that the hybrid zone was stable in position and width (Castiglia \& Capanna, 1999b). In the present study, we further analyse this hybrid zone by performing a direct measurement of the fertility (litter size) in male and female laboratory-reared F1 hybrids with a wild genetic background. In addition, in homozygotes and wild hybrids with different numbers of trivalents, we analysed the frequency of aneuploidy resulting from anaphase I nondisjunction at MII and the frequency of diakinesis showing $\mathrm{X}-\mathrm{Y}$ separation at metaphase $\mathrm{I}$. These data were compared with those of Rizzoni \& Spirito $(1998,1999)$ to detect differences in the level of subfertility in the wild hybrids over time. Indeed, it might be expected that, with time, natural selection would tend to minimize meiotic aberrations in Robertsonian heterozygotes (Wallace et al., 1992). Furthermore, segregation of $\mathrm{Rb}$ metacentrics was evaluated from karyotype data in the offspring obtained from the crosses and from observation of MIIs in wild mice with multiple heterozygosities. These observations are discussed in relation to the stability of this hybrid zone through time.

\section{Materials and method}

\section{Laboratory-reared homozygotes and heterozygotes}

The homozygotes used for the crosses belong to the marginal populations of the transect where the pure races live (described in Castiglia \& Capanna, 1999b). We used 19 mice of the $2 n=40$ race: 18 wild mice trapped in 2 localities (17 from Madonna del Mattone - MDM - and one from Colle Paradiso - CPA) and 1 laboratory-reared mouse. There were 22 mice of the $2 n=22 \mathrm{CD}$ race: 10 wild specimens trapped in 4 localities (7 from Mole B - MOL-B; 1 from Le Mole - MOL; 1 from Le Mole A - MOL-A; 1 from San Sebastiano - SEB) and 12 from the progeny of intraracial crosses. The maximum distance between sampled populations is $17 \mathrm{~km}$ (between MOL-B and MDM). Eleven male and 8 female F1 hybrids, obtained from the interracial crosses, were backcrossed to mice belonging to pure races. All crosses were performed in standard laboratory conditions. Food, water and nesting materials were provided ad libitum, and occasionally fresh fruit as a source of vitamins. The details of the number and types of crosses are given in Table 1. The total number of mice reported in the tables is greater than the number reported above because some mice were used in different crosses. The pairs were allowed to mate freely for a period between 2 and 17 months.

Ninety-one offspring belonging to all the types of crosses involving a heterozygous $\mathrm{F} 1$ male or female were karyotyped using the air-drying technique (Hsu \& Patton, 1969). G-banding was performed on 78 of these mice according to the method of Seabright (1971). A spermatocyte preparation was performed for one laboratory-reared F1 male (see below for details).

Table 1 Reproductive success and litter size in the different crosses

\begin{tabular}{|c|c|c|c|c|c|}
\hline \multirow[b]{2}{*}{ Cross } & \multirow[b]{2}{*}{$\begin{array}{l}\text { No. pairs } \\
(\mathrm{m} / \mathrm{f})\end{array}$} & \multicolumn{2}{|c|}{ No. pairs } & \multirow[b]{2}{*}{$\begin{array}{l}\text { No. } \\
\text { litters }\end{array}$} & \multirow[b]{2}{*}{$\begin{array}{l}\text { Litter } \\
\text { size }\end{array}$} \\
\hline & & $\begin{array}{l}\text { with } \\
\text { litter }\end{array}$ & $\begin{array}{c}\text { without } \\
\text { litter }\end{array}$ & & \\
\hline $40 \times 40$ & $7(6 / 6)$ & 4 & 3 & 15 & $4.5 \pm 1.5$ \\
\hline $22 \times 22$ & $7(4 / 7)$ & 5 & 2 & 24 & $6.2 \pm 1.9$ \\
\hline $\mathrm{m} 40 \times \mathrm{f} 22$ & $3(3 / 3)$ & 2 & 1 & 7 & $6.9 \pm 1.6$ \\
\hline $\mathrm{m} 22 \times \mathrm{f} 40$ & $3(2 / 3)$ & 3 & 0 & 10 & $5.8 \pm 1.3$ \\
\hline $\mathrm{m} 31 \times \mathrm{f} 40$ & $6(5 / 6)$ & 5 & 1 & 14 & $3.0 \pm 1.1$ \\
\hline $\mathrm{m} 31 \times \mathrm{f} 22$ & $6(6 / 5)$ & 6 & 0 & 15 & $3.6 \pm 1.3$ \\
\hline $\mathrm{m} 40 \times \mathrm{f} 31$ & $2(2 / 1)$ & 2 & 0 & 7 & $4.4 \pm 2.1$ \\
\hline $\mathrm{m} 22 \times \mathrm{f} 31$ & $7(4 / 7)$ & 4 & 3 & 7 & $3.0 \pm 1.0$ \\
\hline
\end{tabular}




\section{Wild-caught hybrids}

Spermatocyte preparations were performed according to Evans et al. (1964) for 17 wild mice from five localities along the transect (Table 3). Meiotic preparations were C-banded according to Sumner (1972). We estimated the frequency of aneuploidy (12 mice) by doubling the frequencies of $n+1$ and $n+3$ and quadrupling that of $n+2$ and $n+4$ MII to take into account complementary hypoploids and double aneuploid pseudoeuploids (Rizzoni \& Spirito, 1998). The frequencies of MI with $\mathrm{X}-\mathrm{Y}$ dissociation were recorded in 14 mice. To assess the segregation of the different chromosomal forms ( $\mathrm{Rb}$ and non- $\mathrm{Rb}$ ) in wild mice, we counted the number of metacentric chromosomes inherited in MII for five males.

\section{Statistical analysis}

The statistical analysis was performed with the STATISTICA 3.5 program to evaluate differences in litter size (ANOVA) and reproductive success (Fisher's exact test). Deviations from Mendelian expectations (50:50) in the segregating Robertsonian metacentrics were assessed for all $\mathrm{Rbs}$ together, for each $\mathrm{Rb}$ separately and in the MII cells with $\chi^{2}$ test. To evaluate nonindependent segregation of Rbs, we tested if the number of individuals with different numbers of inherited metacentrics $(0-9)$ followed the binomial distribution with a transmission rate equal to the observed one. For the 78 G-banded mice, we performed a test for genotypic linkage disequilibrium using GENEPOP 3.1. The $H_{0}$ is: genotypes at one locus are independent of the genotypes at other loci. The program creates contingency tables for all pairs of $\mathrm{Rb}$ chromosomes and performs Fisher's exact tests for all tables. Correlation between the length of the different Rbs and their TRm (transmission rate of metacentrics) was ascertained. The total lengths of the metacentrics $(\mathrm{Lm})$ was calculated as the sum of the lengths of each telocentric, expressed as a percentage of the mitotic haploid complement, as reported in Nesbitt \& Francke (1973): $\mathrm{Rb}(1.7), \quad \mathrm{Lm}=12.63 ; \mathrm{Rb}(2.18), \quad \mathrm{Lm}=10.57$; $\mathrm{Rb}(3.8), \mathrm{Lm}=11.10 ; \mathrm{Rb}(4.15), \mathrm{Lm}=10.06 ; \mathrm{Rb}(5.17)$, $\mathrm{Lm}=9.54 ; \mathrm{Rb}(6.13), \mathrm{Lm}=10.00 ; \mathrm{Rb}(9.16), \mathrm{Lm}=8.82$; $\mathrm{Rb}(10.11), \mathrm{Lm}=9.46 ; \mathrm{Rb}(12.14), \mathrm{Lm}=8.94$.

\section{Results}

\section{Reproductive success and litter size}

Reproductive success is expressed as the effective production of progeny by a pair of mice. In some types of crosses, there is a certain proportion of pairs with no progeny (Table 1). Reproductive success is higher in the interracial crosses than in the intraracial ones $(83 \%$ vs. $64 \%$ ), but the difference is not significant (Fisher's exact test $\chi^{2}=0.73, P=0.39$ ). The reproductive success in the crosses between homozygotes is not significantly different from that in the crosses between heterozygotes and homozygotes (Fisher's exact test $\chi^{2}=0.67, P=0.41$ ). No significant difference was found between male and female heterozygotes (Fisher's exact test $\chi^{2}=2.08$, $P=0.15$ ).

Table 1 shows the mean litter size for all types of crosses performed. Preliminary anovas testing differences between pairs within types of crosses detected intracross homogeneity: $40 \times 40 \quad(F=0.43$, d.f. $=3$, $P>0.05) ; 22 \times 22(F=0.92$, d.f. $=4, P>0.05) ; \mathrm{m} 40 \times$ f22 $(F=0.43$, d.f. $=1, P>0.05) ; \mathrm{m} 22 \times \mathrm{f} 40(F=0.01$, d.f. $=2, P>0.05)$; crosses between heterozygotes and homozygotes $(F=1.16$, d.f. $=16, P>0.05)$. The differences between type of crosses, tested by ANOvA, are shown in Table 2 . The mean litter size in $40 \times 40$ crosses (4.5) is significantly lower than that in $22 \times 22$ crosses (6.2). The heteroracial pairs $\mathrm{m} 22 \times \mathrm{f} 40$ and $\mathrm{m} 40 \times \mathrm{f} 22$ have a litter size comparable with that of the $22 \times 22$ crosses. Thus, when a 22 male or female is part of the cross, the mean litter size of the cross increases. Heterozygotes generally have smaller litters than homozygotes. The $\mathrm{m} 31 \times \mathrm{f} 40$ crosses have a smaller litter than the $40 \times 40$ crosses but there is no significant difference in mean litter size between the $\mathrm{m} 40 \times \mathrm{f} 31$ and the $40 \times 40$ crosses. There are greater differences in litter size between the $22 \times 22$ crosses and the $\mathrm{m} 22 \times \mathrm{f} 31$ and $\mathrm{m} 31 \times \mathrm{f} 22$ crosses. No significant differences are found between male and female heterozygotes.

\section{Aneuploidy in metaphase II and $X-Y$ dissociation}

Table 3 shows aneuploidy rates in 12 wild-caught males and in 1 laboratory-reared F1 male, and the frequencies of diakinesis with $\mathrm{X}-\mathrm{Y}$ dissociation in 15 males. The frequency of NDJ increases with the number of heterozygous centric fusions, from a value of $4-10 \%$ in homozygotes to $24-39 \%$ in the mice with 5 trivalents. The F1 individual has the highest NDJ value $(57 \%)$. The mouse SB84, with four trivalents, has a NDJ value of 0.09 . This value is comparable with those obtained from individuals with $0-1$ trivalents. The frequencies of NDJ against the number of trivalents between the actual sample and the past one (Rizzoni \& Spirito, 1998) are shown in Fig. 1 which confirm the increase of NDJ with the number of trivalents. However, in our data the NDJ levels are lower than in the previous sample. In fact, those authors found up to $50 \%$ of aneuploidy in male mice heterozygous for four $\mathrm{Rb}$ fusions, whereas in our study the two males with 5 trivalents have lower NDJ values 
Table 2 Summary of ANOva results for litter size of different types of crosses

\begin{tabular}{lrrrr}
\hline Crosses & $\begin{array}{r}\text { Sum of } \\
\text { squares }\end{array}$ & d.f. & \multicolumn{1}{c}{$F$} & $P$ \\
\hline$(40 \times 40)$ vs. $(22 \times 22)$ & 28.001 & 1 & 11.008 & 0.001 \\
$(40 \times 40)$ vs. $(40 \times 22)$ & 27.270 & 1 & 10.722 & 0.001 \\
$(40 \times 40)$ vs. $(\mathrm{m} 22 \times \mathrm{f} 40)$ & 10.667 & 1 & 4.193 & 0.043 \\
$(40 \times 40)$ vs. $(\mathrm{m} 31 \times \mathrm{f} 40)$ & 15.577 & 1 & 6.124 & 0.015 \\
$(40 \times 40)$ vs. $(\mathrm{m} 40 \times \mathrm{f} 31)$ & 0.007 & 1 & 0.003 & 0.960 \\
$(22 \times 22)$ vs. $(\mathrm{m} 40 \times \mathrm{f} 22)$ & 2.281 & 1 & 0.897 & 0.346 \\
$(22 \times 22)$ vs. $(\mathrm{m} 22 \times \mathrm{f} 40)$ & 1.177 & 1 & 0.462 & 0.498 \\
$(22 \times 22)$ vs. $(\mathrm{m} 31 \times \mathrm{f} 22)$ & 62.801 & 1 & 24.690 & $<0.001$ \\
$(22 \times 22)$ vs. $(\mathrm{m} 22 \times \mathrm{f} 31)$ & 55.783 & 1 & 21.931 & $<0.001$ \\
$(\mathrm{~m} 22 \times \mathrm{f} 40)$ vs. $(\mathrm{m} 40 \times \mathrm{f} 22)$ & 4.602 & 1 & 1.809 & 0.182 \\
$(40 \times 40)$ vs. $(\mathrm{m} 40 \times \mathrm{f} 31$ plus $\mathrm{m} 31 \times \mathrm{f} 40)$ & 4.708 & 1 & 1.851 & 0.177 \\
$(22 \times 22)$ vs. $(\mathrm{m} 31 \times 22$ plus $\mathrm{m} 22 \times \mathrm{f} 31)$ & 32.412 & 1 & 12.742 & $<0.001$ \\
$(\mathrm{~m} 31 \times \mathrm{f} 40)$ vs. $(\mathrm{m} 40 \times \mathrm{f} 31)$ & 9.524 & 1 & 3.744 & 0.056 \\
$(\mathrm{~m} 31 \times \mathrm{f} 22)$ vs. $(\mathrm{m} 22 \times \mathrm{f} 31)$ & 1.718 & 1 & 0.675 & 0.413 \\
Error & 231.463 & 91 & & \\
\hline
\end{tabular}

(24-39\%). Simple linear regression analyses explain the pattern of variation in the present and in the past sample $\left(R^{2}=0.82\right.$ and $R^{2}=0.96$, respectively). The slope of the regression line was lower in the present than in the past (a gain of 0.05 and 0.11 , respectively, in NDJ frequency for each adding trivalent). The frequencies of MI with $\mathrm{X}-\mathrm{Y}$ dissociation are quite low in all the specimens analysed. A slight increase of $\mathrm{X}-\mathrm{Y}$ disjunction is present in mouse SB84 with four trivalents (12.6\% of MI dissociated).

\section{Segregation in multiple heterozygotes}

The overall transmission rate of metacentrics (TRm) in all 91 backcrosses (Table 4) conforms with the Mendelian expectation $(\mathrm{TRm}=0.5)(407$ metacentrics vs. 413 telocentrics). No deviations from Mendelian ratios were observed within backcross types (males and females pooled) or within sex categories (heterozygous males: 248 metacentrics vs. 248 telocentrics; heterozygous females: 159 metacentrics vs. 165 telocentrics). A slight deviation from the Mendelian expectation was observed in the $\mathrm{m} 22 \times \mathrm{f} 31$ crosses, in favour of the telocentric chromosomes $(53$ metacentrics vs. 73 telocentrics; $\left.\chi^{2}=3.17 P=0.07\right)$. The results of the test for independent transmission of different $\mathrm{Rbs}$ agree with expectations in the total sample and in male heterozygotes. In female heterozygotes, there is a slight departure from the expected distribution of karyotypes in backcrosses $\left(\chi^{2}=17.37\right.$, d.f. $\left.=9, P=0.04\right)$ : the number of backcrosses with 2 and 7 metacentrics is greater than expected and the number of backcrosses with 3 and 6 metacentrics is lower than expected.
Table 5 reports the transmission rate of each $\mathrm{Rb}$ separately inferred from the karyotype of the backcrosses born from heterozygous males (42 individuals: 15 from the $\mathrm{m} 31 \times \mathrm{f} 40$ crosses and 27 from the $\mathrm{m} 31 \times \mathrm{f} 22$ crosses) and heterozygous females (36 individuals: 22 from the $\mathrm{m} 40 \times \mathrm{f} 31$ crosses and 14 from the $\mathrm{m} 22 \times \mathrm{f} 31$ crosses). Significant deviations from Mendelian expectations were found in the backcrosses born from the $\mathrm{m} 31 \times \mathrm{f} 40$ crosses for $\mathrm{Rb}(12.14)$ in favour of the Robertsonian metacentric $\left(\chi^{2}=5.4, P=0.02\right)$. However, after application of the Bonferroni correction for multiple testing this deviation is not significant. Other distortions of the TRm are present in all types of crosses. These distortions involve six Rbs $(4.15,12.14$, $9.16,2.18,6.13$ and 1.7) for which the $\chi^{2}$ values appear high. The $\chi^{2}$ value for heterogeneity is high in all types of crosses except $\mathrm{m} 22 \times \mathrm{f} 31$, indicating that deviations of the different $\mathrm{Rbs}$ are not homogeneous and that different $\mathrm{Rbs}$ are sometimes in excess in some of the progeny and in deficit in the others. There is no correlation between the TRm values of males and females (Spearman Coefficient of Correlation $r=0.36$, $P=0.34$ ). A negative correlation was found between the lengths of the $\mathrm{Rb}$ metacentrics and their transmission rates in the total sample $(r=-0.74, P=0.02)$ and in males $(r=-0.77, P=0.01)$. In the females the correlation is negative but not significantly different from zero $(r=-0.35, P=0.35)$. A scatterplot is shown in Fig. 2 .

We tested the independence of segregation of different Rbs by analysing the genotypic disequilibrium in the backcross progeny. The test was performed separately in all offspring arising from male and female heterozygotes and, within these groups, in the offspring with different 


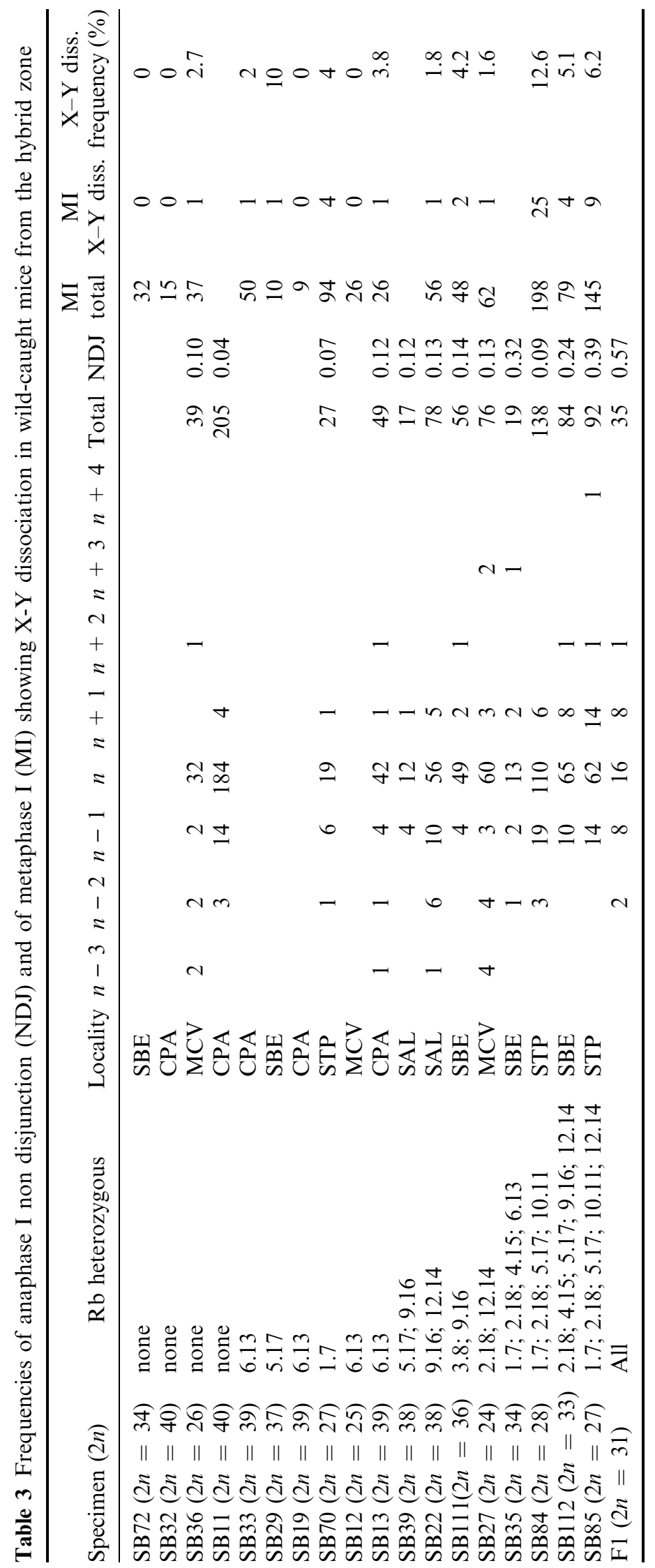

(C) The Genetical Society of Great Britain, Heredity, 85, 147-156. 


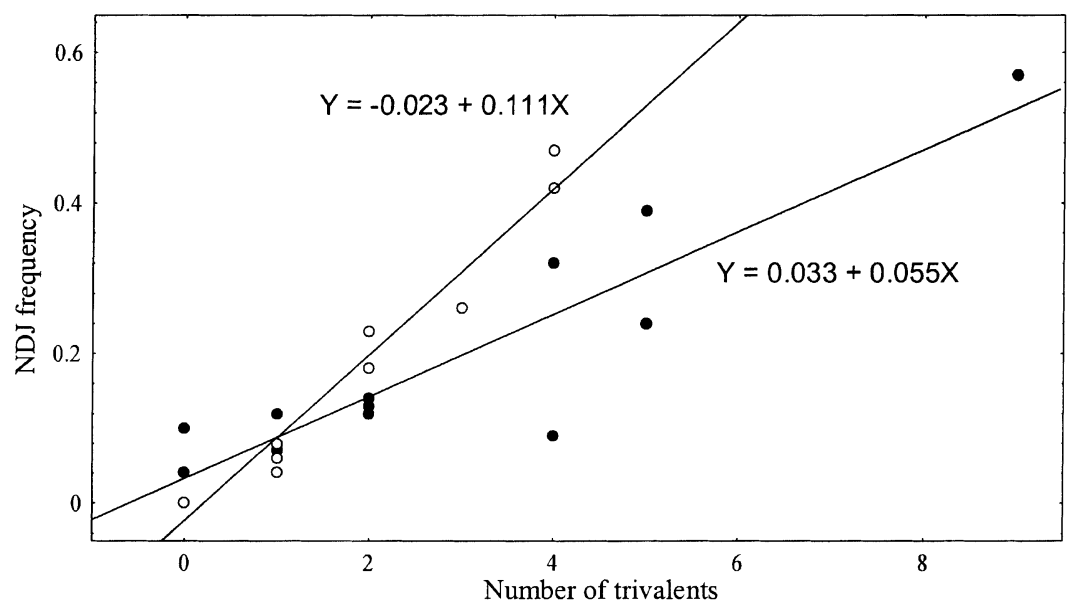

Table 4 Number of backcrosses inheriting 0-9 Robertsonian metacentrics and overall transmission rate for metacentrics (TRm)

\begin{tabular}{|c|c|c|c|c|c|c|c|c|c|c|c|c|c|c|}
\hline \multirow{2}{*}{$\begin{array}{l}\text { Type of } \\
\text { crosses }\end{array}$} & \multicolumn{10}{|c|}{ No. of backcrosses with 0-9 metacentrics } & \multirow[b]{2}{*}{ Tot. } & \multirow[b]{2}{*}{$\mathrm{Rb}$} & \multirow[b]{2}{*}{+} & \multirow[b]{2}{*}{$\mathrm{TRm}$} \\
\hline & 0 & 1 & 2 & 3 & 4 & 5 & 6 & 7 & 8 & 9 & & & & \\
\hline $\mathrm{m} 31 \times \mathrm{f} 40$ & 0 & 0 & 2 & 4 & 10 & 6 & 2 & 2 & 0 & 0 & 26 & 112 & 122 & 0.48 \\
\hline $\mathrm{m} 31 \times \mathrm{f} 22$ & 0 & 1 & 0 & 7 & 7 & 4 & 4 & 6 & 0 & 0 & 29 & 136 & 126 & 0.52 \\
\hline $\mathrm{m} 40 \times \mathrm{f} 31$ & 0 & 0 & 3 & 2 & 5 & 5 & 2 & 4 & 0 & 1 & 22 & 106 & 92 & 0.55 \\
\hline $\mathrm{m} 22 \times \mathrm{f} 31$ & 0 & 1 & 2 & 2 & 4 & 4 & 1 & 0 & 0 & 0 & 14 & 53 & 73 & 0.42 \\
\hline Total & 0 & 2 & 6 & 14 & 26 & 19 & 8 & 12 & 0 & 1 & 91 & 407 & 413 & 0.50 \\
\hline
\end{tabular}

Fig. 1 Number of trivalent against NDJ frequency in male mice according to present observation (closed circles) and Rizzoni \& Spirito (1999) (open circles). Regression lines are plotted through the data points. homozygote parents. Of the 144 contingency tables examined, 11 are significant $(P<0.05)$ and 4 are close to being significant $0.05<P<0.06$ (Table 6); these include 11 different pairs of Rbs. After application of the Bonferroni correction none of these results is significant. However, in 12 of these 15 tables (Table 6), the chromosomes with the same morphology $(\mathrm{Rb}-\mathrm{Rb}$ and non $\mathrm{Rb}$-nonRb) are associated more frequently than those with a different morphology (Rb-nonRb), while chromosomes with a different morphology are in excess in the progeny in only 3 tables.

The analysis of segregation in MII (Table 7) revealed that the TRm values are higher than 0.5 in all the males analysed, although the difference is not significant. For all MIIs, $\mathrm{TRm}=0.53$ (560 Rb vs. 503 tel.) $\left(\chi^{2}=3.75\right.$ $P=0.08)$. The distribution of the number of MIIs with different numbers of metacentrics conforms with the binomial distribution; thus, on the basis of the observation of MII cells, Rbs segregate randomly with respect to one another.

\section{Discussion}

Our data suggest that, in this hybrid zone, male and female F1 heterozygotes have the same reproductive success as homozygote individuals, and intraracial crosses have the same reproductive success as the interracial ones. Contrasting results were found in a Tunisian hybrid zone between a $2 n=22$ Robertsonian race and the Standard population; lower reproductive success was found in crosses between F1 heterozygotes and homozygotes than in crosses between homozygotes by Said et al. (1993). Opposite results, i.e. no differences, were found by Chatti (1999) in the same hybrid area; moreover, he emphasizes a higher reproductive success in males than in females.

We found differences in litter size between the chromosomal races, the standard one being less fertile than the CD race. Said et al. (1993) found that the standard race fits better than the Robertsonian one, while opposite results where stressed by Chatti (1999). Consequently the differences in litter size between chromosomal races are not necessarily related to a selective advantage of one chromosomal race over the other in every environmental condition, but they may be a consequence of selective factors acting locally or may represent a different demographic strategy related to habitat segregation as stated by Said et al. (1993) and Castiglia \& Capanna (1999b). Significantly, Castiglia \& Capanna (1999b) did not find a shift in the 
position of the zone in 20 years (which is more or less 100 generations). Using the model of Barton (1979), which shows how a tension zone can move in response to a selective imbalance between the two homozygotes, they demonstrated that even a small advantage of one race over the other (for example, between 1 and $8 \%$ )

Table 5 Segregation of Rbs of heterozygous mice. * indicates the statistically significant value

\begin{tabular}{|c|c|c|c|c|c|c|c|c|c|c|c|c|}
\hline \multirow[b]{2}{*}{ Males } & \multicolumn{4}{|c|}{$\mathrm{m} 31 \times \mathrm{f} 40$} & \multicolumn{4}{|c|}{$\mathrm{m} 31 \times \mathrm{f} 22$} & \multicolumn{4}{|c|}{ Total } \\
\hline & $\mathrm{Rb}$ & + & TRm & $\chi^{2}$ (d.f.) & $\mathrm{Rb}$ & + & $\mathrm{TRm}$ & $\chi^{2}$ (d.f.) & $\mathrm{Rb}$ & + & $\mathrm{TRm}$ & $\chi^{2}$ (d.f.) \\
\hline $\mathrm{Rb}(1.7)$ & 6 & 9 & 0.40 & $0.6(1)$ & 9 & 18 & 0.33 & $3(1)$ & 15 & 27 & 0.35 & $3.4(1)$ \\
\hline $\mathrm{Rb}(2.18)$ & 6 & 9 & 0.40 & $0.6(1)$ & 18 & 9 & 0.67 & $3(1)$ & 24 & 18 & 0.57 & $0.8(1)$ \\
\hline $\mathrm{Rb}(3.8)$ & 5 & 10 & 0.33 & $1.7(1)$ & 14 & 13 & 0.52 & $0.4(1)$ & 19 & 23 & 0.45 & $0.4(1)$ \\
\hline $\mathrm{Rb}(4.15)$ & 11 & 4 & 0.73 & $3.3(1)$ & 10 & 17 & 0.37 & $1.8(1)$ & 21 & 21 & 0.5 & $0(1)$ \\
\hline $\mathrm{Rb}(5.17)$ & 6 & 9 & 0.40 & $0.6(1)$ & 13 & 14 & 0.48 & $0.4(1)$ & 19 & 23 & 0.45 & $0.4(1)$ \\
\hline $\operatorname{Rb}(6.13)$ & 7 & 8 & 0.47 & $0.1(1)$ & 14 & 13 & 0.52 & $0.4(1)$ & 21 & 21 & 0.5 & $0(1)$ \\
\hline $\mathrm{Rb}(9.16)$ & 7 & 8 & 0.47 & $0.1(1)$ & 19 & 8 & 0.7 & $3(1)$ & 26 & 16 & 0.62 & $2.4(1)$ \\
\hline $\mathrm{Rb}(10.11)$ & 8 & 7 & 0.53 & $0.1(1)$ & 16 & 11 & 0.59 & $0.9(1)$ & 24 & 18 & 0.57 & $0.8(1)$ \\
\hline $\mathrm{Rb}(12.14)$ & 12 & 3 & 0.80 & $5.4 *(1)$ & 15 & 12 & 0.55 & $0.3(1)$ & 27 & 15 & 0.64 & $3.5(1)$ \\
\hline Pooled & 68 & 67 & 0.50 & $0.0(1)$ & 128 & 115 & 0.53 & $0.69(1)$ & 196 & 182 & 0.52 & $0.5(1)$ \\
\hline Total & & & & $12.5(8)$ & & & & $12.8(8)$ & & & & $11.8(8)$ \\
\hline \multirow[t]{2}{*}{ Heterogeneity } & & & & $12.5(7)$ & & & & $12.1(7)$ & & & & $11.2(7)$ \\
\hline & \multicolumn{4}{|c|}{$\mathrm{m} 40 \times \mathrm{f} 31$} & \multicolumn{4}{|c|}{$\mathrm{m} 22 \times \mathrm{f} 31$} & \multicolumn{4}{|c|}{ Total } \\
\hline Males & $\mathrm{Rb}$ & + & TRm & $\chi^{2}$ (d.f.) & $\mathrm{Rb}$ & + & $\mathrm{TRm}$ & $\chi^{2}$ (d.f.) & $\mathrm{Rb}$ & + & TRm & $\chi^{2}$ (d.f.) \\
\hline $\mathrm{Rb}(1.7)$ & 7 & 15 & 0.32 & $2.9(1)$ & 6 & 8 & 0.43 & $0.3(1)$ & 13 & 23 & 0.36 & $2.8(1)$ \\
\hline $\mathrm{Rb}(2.18)$ & 11 & 11 & 0.50 & $0.0(1)$ & 8 & 6 & 0.57 & $0.3(1)$ & 19 & 17 & 0.53 & $0.1(1)$ \\
\hline $\mathrm{Rb}(3.8)$ & 10 & 12 & 0.45 & $0.2(1)$ & 6 & 8 & 0.43 & $0.3(1)$ & 16 & 20 & 0.44 & $0.4(1)$ \\
\hline $\mathrm{Rb}(4.15)$ & 9 & 13 & 0.41 & $0.7(1)$ & 6 & 8 & 0.43 & $0.3(1)$ & 15 & 21 & 0.42 & $1.0(1)$ \\
\hline $\operatorname{Rb}(5.17)$ & 11 & 11 & 0.50 & $0.0(1)$ & 6 & 8 & 0.43 & $0.3(1)$ & 17 & 19 & 0.47 & $0.1(1)$ \\
\hline $\mathrm{Rb}(6.13)$ & 15 & 7 & 0.68 & $2.9(1)$ & 4 & 10 & 0.28 & $2.6(1)$ & 19 & 17 & 0.53 & $0.1(1)$ \\
\hline $\mathrm{Rb}(9.16)$ & 12 & 10 & 0.54 & $0.2(1)$ & 6 & 8 & 0.43 & $0.3(1)$ & 18 & 18 & 0.5 & $0.0(1)$ \\
\hline $\mathrm{Rb}(10.11)$ & 14 & 8 & 0.64 & $1.6(1)$ & 7 & 7 & 0.5 & $0(1)$ & 21 & 15 & 0.58 & $1.0(1)$ \\
\hline $\mathrm{Rb}(12.14)$ & 11 & 11 & 0.50 & $0.0(1)$ & 4 & 10 & 0.28 & $2.6(1)$ & 15 & 21 & 0.42 & $1.0(1)$ \\
\hline Pooled & 100 & 98 & 0.50 & $0.0(1)$ & 53 & 73 & 0.42 & $3.2(1)$ & 153 & 171 & 0.47 & $1.0(1)$ \\
\hline Total & & & & $8.5(8)$ & & & & $7(8)$ & & & & $6.5(8)$ \\
\hline Heterogeneity & & & & $8.5(7)$ & & & & $3.8(7)$ & & & & $5.5(7)$ \\
\hline
\end{tabular}

Fig. 2 Length of the different Robertsonian metacentrics (percentage of the mitotic haploid complement) against their transmission rate (TRm). Males (closed circles), females (open circles) and total sample (bars).

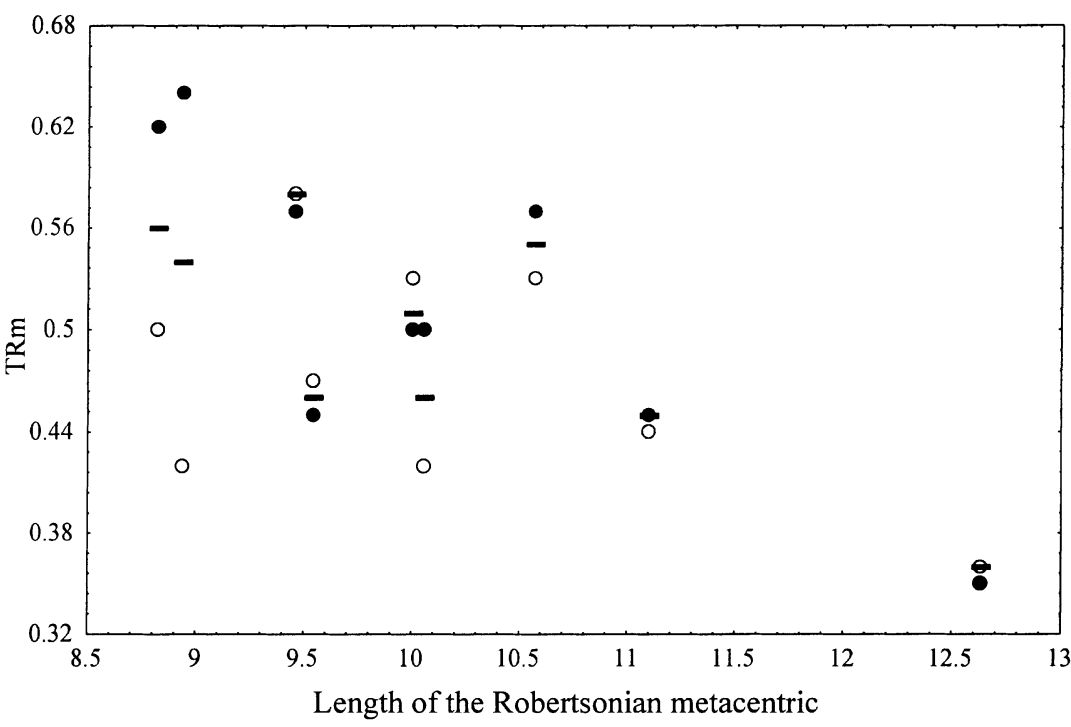

(C) The Genetical Society of Great Britain, Heredity, 85, 147-156. 
could give rise to an appreciable shift of the transect (2275 and $18200 \mathrm{~m}$, respectively). The observed difference in litter size is equivalent to an advantage of the Robertsonian race equal to 0.38 , which should have been able to produce a shift of $86450 \mathrm{~m}$.

Interracial crosses produce litter sizes comparable to those of the $22 \times 22$ crosses. This means that crosses involving a male or female $\mathrm{CD}$ individual will have an increased litter size compared to $40 \times 40$. An opposite effect was observed in females of $M . m$. domesticus by Said et al. (1993) and in both sexes in Suncus murinus by Rogatcheva et al. (1998): in interracial crosses, the less fertile individuals reduced the litter size of the more fertile ones.

Table 6 Pairs of metacentric chromosomes showing a significant or a near significant linkage disequilibrium in offspring of multiple heterozygous mice. Positive/negative associations $(+/-)$ indicate that chromosomes with a similar/different morphology are in excess with respect to those with a different/similar morphology

\begin{tabular}{llcc}
\hline Type of cross & \multicolumn{1}{c}{ Rbs } & $P$ & Association \\
\hline Total females het. & 2.18 and 4.15 & 0.040 & + \\
& 2.18 and 9.16 & 0.006 & - \\
& 4.15 and 10.11 & 0.039 & + \\
& 6.13 and 10.11 & 0.014 & + \\
& 3.8 and 12.14 & 0.018 & - \\
& 6.13 and 12.14 & 0.051 & + \\
& 10.11 and 12.14 & 0.006 & + \\
$\mathrm{m} 40 \times \mathrm{f} 31$ & 2.18 and 9.16 & 0.030 & - \\
& 6.13 and 10.11 & 0.002 & + \\
& 6.13 and 12.14 & 0.062 & + \\
Total males het. & 1.7 and 4.15 & 0.052 & + \\
& 2.18 and 10.11 & 0.063 & + \\
$\mathrm{m} 31 \times \mathrm{f} 40$ & 1.7 and 9.16 & 0.040 & + \\
$\mathrm{m} 31 \times \mathrm{f} 22$ & 1.7 and 4.15 & 0.037 & + \\
& 3.8 and 4.15 & 0.045 & + \\
\hline
\end{tabular}

In our study, the F1 heterozygotes have a smaller mean litter size than the homozygotes. The differences in litter size between homozygotes and heterozygotes seem to be smaller than previously reported (Said et al., 1993; Hauffe \& Searle, 1998) and are consistent with the different widths of the hybrid zones.

In male heterozygotes, the litter size is $33 \%$ and $41 \%$ smaller than those of the respective parental races. The $\mathrm{m} 22 \times \mathrm{f} 31$ crosses show a reduction of $52 \%$, while the $\mathrm{m} 40 \times \mathrm{f} 31$ crosses have a litter size comparable with that of the $40 \times 40$ crosses, although in the former the variability in litter size is greater. In addition, the maximum number of offspring produced by female heterozygotes can be very high (8).

The NDJ values found in the present samples are lower than corresponding values found in the past. However, these temporal differences do not seem sufficient to invoke a diminution of meiotic malsegregation with time, because the two samples are not very large, and variation in NDJ frequencies has been found in individuals with the same number of trivalents. Subsequent temporal analyses could reveal whether the trend is real or whether differences result from sampling errors. As suggested by Burgoyne \& Biddle (1980), cells with an X and Y univalent fail to contribute to MII; the values of $\mathrm{X}-\mathrm{Y}$ disjunction (0-13\%) found in this hybrid zone are in the lower half of the range of values reported in the literature (Hauffe \& Searle, 1998) and they do not affect the fertility of mice from this hybrid zone.

The values of fertility that we found in wild and laboratory-reared mice are in accordance with the idea that a single segregating fusion is only a marginally underdominant marker. Higher numbers of metacentrics in the heterozygous condition have a more severe impact on fertility. This pattern has implications for models of chromosomal speciation (White, 1978) which hypothesize a progressive accumulation of single metacentrics in small isolated demes.

Table 7 Number of MII with different numbers of metacentrics observed in spermatocyte preparations from wild mouse hybrids. Diploid number and identity of metacentrics in a heterozygous condition are indicated in Table 3

\begin{tabular}{|c|c|c|c|c|c|c|c|c|c|c|c|}
\hline \multirow[b]{2}{*}{ Specimen } & \multirow[b]{2}{*}{ No. MII } & \multicolumn{6}{|c|}{ Number of MII with $\mathrm{N}$ metacentrics } & \multirow[b]{2}{*}{$\mathrm{Rb}$} & \multirow[b]{2}{*}{+} & \multirow[b]{2}{*}{ TRm } & \multirow[b]{2}{*}{$\chi^{2}$ (d.f.) } \\
\hline & & 0 & 1 & 2 & 3 & 4 & 5 & & & & \\
\hline SB27 & 50 & 6 & 33 & 11 & & & & 55 & 45 & 0.58 & $2.7(1)$ \\
\hline SB111 & 36 & 7 & 19 & 10 & & & & 39 & 33 & 0.54 & $0.5(1)$ \\
\hline SB84 & 86 & 7 & 18 & 24 & 28 & 9 & & 186 & 158 & 0.54 & $2.3(1)$ \\
\hline SB85 & 49 & 1 & 6 & 20 & 12 & 8 & 2 & 124 & 121 & 0.51 & $0.0(1)$ \\
\hline SB112 & 62 & 2 & 10 & 20 & 18 & 8 & 4 & 156 & 146 & 0.52 & $0.3(1)$ \\
\hline Pooled & & & & & & & & 560 & 503 & 0.53 & $3.1(1)$ \\
\hline Total & & & & & & & & & & & $5.8(4)$ \\
\hline Heterogen & & & & & & & & & & & $2.7(3)$ \\
\hline
\end{tabular}


The transmission analysis shows that the overall segregation conforms closely with Mendelian expectations; however, some slight deviations from Mendelian segregation are revealed when single $\mathrm{Rb}$ metacentrics are taken into account. These deviations sometimes favour the $\mathrm{Rb}$ metacentrics and at other times favour the telocentric chromosomes. It is possible that selective processes, acting at the meiotic level, favour some $\mathrm{Rbs}$ and disadvantage others (or treat them as neutral). The correlation between chromosome length and TRm is an original finding in mice and may provide an explanation for the differences observed. In fact, we found that large metacentrics have a lower TRm while small ones have a higher TRm. Although we cannot explain this observation, we suggest that this trend is consistent with the fact that the fusions shared by the three races of the Apennine Robertsonian system are among the smaller ones: $\mathrm{Rb}(9.16)$ is common to $\mathrm{CD}$ and $\mathrm{CB}$, while $\mathrm{Rb}(10.12)$ and $\mathrm{Rb}(8.14)$ are shared by $\mathrm{ACR}$ and $\mathrm{CB}$. This observation can be extended to the complex of chromosomal races of the Rhaetian Alps. In this area exist 10 different chromosomal races with a diploid number ranging from $2 n=26$ to $2 n=22$ (Hauffe \& Piálek, 1997). Among the 19 different Robertsonian metacentrics present in the area the most widespread are: $\mathrm{Rb}(5.15), \mathrm{Rb}(11.13)$ (eight races) and $\mathrm{Rb}(9.14)$ and $\mathrm{Rb}(16.17)$ (10 races). All of these metacentrics are small with respect to others present in the area, and $\mathrm{Rb}(16.17)$ and $\mathrm{Rb}(11.13)$ are the smallest. This might be the result of a higher probability of fixation for smaller fusion products than for the larger ones.

The analysis of the independence of the different fusions reveals no significant association between the different Rbs. However, a slight tendency towards positive association is present in males, and in female heterozygotes. In the MII, we found no evidence of cosegregation, although such a feature was reported by Rizzoni \& Spirito (1999) in two animals belonging to the same transect. The magnitude of this force must still be ascertained, because even slight values of cosegregation may have an important effect on the structure of the hybrid zone: the cosegregation would tend to lessen heterozygosity in the central populations, where many metacentrics are in a heterozygous state, and reconstructing the parental genome might stabilize the hybrid zone.

A more thorough study of the chromosomal structure, by means of analyses of Hardy-Weinberg equilibrium and of linkage disequilibrium in populations of the hybrid zone, will reveal whether different metacentrics are under different selective pressures in nature, as suggested by the segregation analysis.

\section{Acknowledgements}

We are grateful to Carlo Alberto Redi and Maria Vittoria Civitelli for their helpful suggestions and to Silvia Garagna for comments on an early draft of the manuscript. Thanks are extended to Luciano Veroli for his technical assistance.

\section{References}

BARTON, N. H. 1979. The dynamics of hybrid zones. Heredity, 43, 341-359.

BRITTON-DAVIDIAN, J., SONJAYA, H., CATALAN, J. AND CATTANEOBERREBI, G. 1990. Robertsonian heterozygosity in wild mice: fertility and transmission rates in $\mathrm{Rb}$ (16.17) translocation heterozygotes. Genetica, 80, 171-174.

BURGOYNE, P. S. AND BIDDLE, F. G. 1980. Spermatocyte loss in XYY mice. Cytogenet. Cell Genet., 28, 143-144.

CAPANNA, E. 1982. Robertsonian numerical variation in animal speciation: Mus musculus an emblematic model. In: Barigozzi, C. (ed.) Mechanism of Speciation, pp. 155-177. Alan Liss, New York.

CASTIGLIA, R. AND CAPANNA, E. 1999a. Whole-arm Reciprocal Translocation (WART) in a feral population of mice. Chromosome Res., 7, 493-495.

CAStiglia, R. AND CAPANNA, E. 1999b. Contact zone between chromosomal races of Mus musculus domesticus. 1. Temporal analysis of an hybrid zone between the CD chromosomal race $(2 n=22)$ and populations with the standard karyotype. Heredity, 83, 319-326.

CHATTI, N. 1999. Differenciation chromosomique chez la souris domestique (Mus musculus domesticus) de Tunisie: Incidence sur la coadaptation genomique et role dans l'isolement reproductif. Dphil. Thesis. Universite de Tunis II.

EVANS, E. P., BRECKON, G. AND FORD, C. E. 1964. An air-drying method for meiotic preparations from mammalian testes. Cytogenetics, 3, 289-294.

GARAGNA, S., REDI, C. A., ZUCCOTTI, M., BRITTON-DAVIDIAN, J. AND WINKING, H. 1989. Kinetics of oogenesis in mice heterozygous for Robertsonian translocations. Differentiation, 42, 167-171.

GROPP, A., TETTENBORN, U. AND VON LEHMANN, E. 1969. Chromosomenuntersuchungen bei der Tabakmaus (M. poschiavinus) und bei den Hybriden mit der Laboratorumsmaus. Experientia, 25, 875-876.

HARRIS, M. J., WALlaCe, M. E. AND EVANS, E. P. 1986. Aneuploidy in the embryonic progeny of females heterozygous for the Robertsonian chromosome (9.12) in genetically wild PeruCoppock mice (Mus musculus). J. Reprod. Fertil., 76, 193-203.

HAUfFE, H. C. AND PIáLEK, J. 1997. Evolution of the chromosomal races of Mus musculus domesticus in the Rhaetian Alps: the roles of whole-arm reciprocal translocation and zonal raciation. Biol. J. Linn. Soc., 62, 255-278.

HAUfFe, H. C. AND SEARle, J. B. 1998. Chromosomal heterozygosity and fertility in house mice (Mus musculus domesticus) from Northern Italy. Genetics, 150, 1143-1154. 
HSU, T. C. AND PATTON, J. L. 1969. Bone marrow preparations for chromosome studies. In: Benirschke, K. (ed.) Comparative Mammalian Cytogenetics, pp. 454-460. Springer, Berlin.

LENORMAND, T., FEL-CLAIR, F., MANOLAKOU, K., ALIBERT, P. AND BRITTON-DAVIDIAN, J. 1997. Chromosomal transmission bias in laboratory hybrids between wild strains of the two European subspecies of house mice. Genetics, 147, 1279-1287.

NACHMAN, M. W. AND SEARLE, J. B. 1995. Why is the house mouse karyotype so variable? Trends Ecol. Evol., 10, 397-402.

NANCE, V., VANLERberghe, F., NIELSEN, J. T., BONHOMME, F. AND BRITTON-DAVIDIAN, J. 1990. Chromosomal introgression in house mouse from the hybrid zone between $M . m$. domesticus and M. m. musculus in Denmark. Biol. J. Linn. Soc., 41, 215-227.

NESBITT, M. N. AND FRANCKE, U. 1973. A system of nomenclature for band patterns of mouse chromosomes. Chromosoma, 41, 145-158.

REDI, C. A., GARAGNA, S., HILSCHER, B. AND WINKING, H. 1985. The effects of some Robertsonian chromosome combinations in the seminiferous epithelium of the mouse. J. Embryol. Exp. Morph., 85, 1-19.

RIZZONI, M. AND SPIRITO, F. 1998. Aneuploidy in metaphases II of spermatocytes of wild house mice from a hybrid zone between a Robertsonian population (CD: $2 n=22)$ and a population with the standard karyotype $(2 n=40)$. Genetica, 101, 225-228.

RIZZONI, M. AND SPIRITO, F. 1999. Nonrandom segregation in multiple Robertsonian heterozygotes in the house mouse (Mus musculus domesticus): analysis of metaphases of spermatocytes II of mice from a hybrid zone between a Robertsonian population and a population with the standard karyotype. Ital. J. Zool., 66, 23-25.

ROGATCHEVA, B. M., ODA, S.-I., AXENOVIC, T. I., AULCHENKO, Y. S., SEARLE, J. B. AND BORODIN, P. M. 1998. Chromosomal segregation and fertility in Robertsonian chromosomal heterozygotes of the house musk shrew (Suncus murinus, Insectivora, Soricidae). Heredity, 81, 335-341.

SAGE, R. D., ATCHLEY, W. R. AND CAPANNA, E. 1992. House mice as models in systematic biology. Syst. Biol., 42, 523-561.

SAID, K., SAAD, A., AUFFRAY, J.-C. AND BRITTON-DAVIDIAN, J. 1993. Fertility estimates in the Tunisian all-acrocentric and Robertsonian populations of the house mouse and their chromosomal hybrids. Heredity, 71, 532-538.

SCRIVEN, P. N. 1992. Robertsonian translocation introduced into an island population of house mice. J. Zool. Lond., 227, 493-502.

SEABRIGHT, M. A. 1971. A rapid banding technique for human chromosomes. Lancet, 2, 971-972.

SPIRITO, F., MODESTI, A., PERTICONE, P., CRISTALDI, M., FEDERICI, R. AND RIZZONI, M. 1980. Mechanisms of fixation and accumulation of centric fusions in natural populations of Mus musculus L. I. Karyological analysis of an hybrid zone between two populations in the central Apennines. Evolution, 34, 453-466.

SUMNER, A. T. 1972. A simple technique for demonstrating centromeric heterochromatin. Exp. Cell Res., 75, 304-306.

VIROUX, M. C. AND BAUCHAU, v. 1992. Segregation and fertility in Mus musculus domesticus (wild mice) heterozygous for the Rb (4.12) translocation. Heredity, 68, 131-134.

WAllace, B. M., SEARle, J. B. AND EVERETT, C. A. 1992. Male meiosis and gametogenesis in wild house mice (Mus musculus domesticus) from a chromosomal hybrid zone; a comparison between 'simple' Robertsonian heterozygotes and homozygotes. Cytogenet. Cell. Genet., 61, 211-220.

WHITE, M. J. D. 1978. Chain processes in chromosomal speciation. Syst. Zool., 27, 285-298.

WINKING, H. B., DULIC, B. AND BULFIELD, G. 1988. Robertsonian karyotype variation in the European house mouse, Mus musculus: survey of present knowledge and new observations. Z. Säugetierk., 53, 148-161. 